\title{
Böbrek Hastalarının Klinikte Yattığı Sürede Öğrenim Gereksinimlerinin Tespiti
}

\author{
Meltem ESKİCIOĞLU ${ }^{1}$, Eda ÜNAL ${ }^{2}$, Aysel ÖZDEMIR ${ }^{3}$
}

1 Bursa Uludağ Üniversitesi Sağlık Bilimleri Enstitüsü, Hemşirelik Anabilim Dalı, Bursa.

2 Bursa Dörtçelik Çocuk Hastalıkları Hastanesi, Bursa.

3 Bursa Uludağ Üniversitesi Sağlık Bilimleri Fakültesi, Halk Sağlığı Hemşireliği Anabilim Dalı, Bursa.

\begin{abstract}
ÖZET
$\mathrm{Bu}$ çalışma, böbrek hastalarının klinikte yattığı süre içerisinde öğrenim gereksinimlerinin belirlenmesi amacıyla tanımlayıcı ve kesitsel olarak planlandı. Araştırma çalışmaya katılmayı kabul eden 134 hasta ile yapıldı. Çalışmanın verileri araştırmacı tarafindan hazırlanan kişisel bilgi formu ve Hasta Öğrenim Gereksinimleri Ölçeği (HÖGÖ) ile toplandı. İstatistiksel analiz için Mann Whitney U testi, Kruskall Wallis

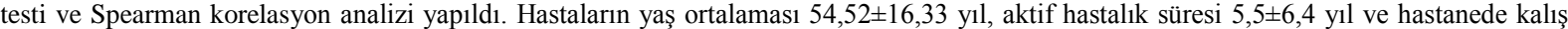
süresi 6,64 $\pm 6,52$ gündür. Hastaların $\% 53$ 'ü kadın $\% 77,6$ 'sı evli, çoğunluğu $(\% 47,8)$ ilkokul mezunu ve ekonomik durumları $(\% 91,0)$ orta düzeydedir. Yas, cinsiyet, eğitim, meslek, ekonomik durum öğrenme ihtiyaçları ile korelasyon gösterdi ( $\mathrm{p}>0.05)$. Çalışmaya katılan nefroloji

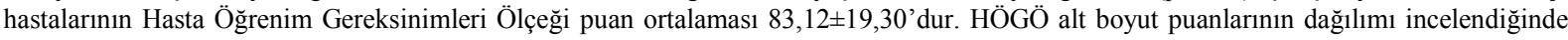
yaşam aktiviteleri $(17,94 \pm 5,72)$ ile tedavi ve komplikasyonlar $(17,04 \pm 5,50)$ bölümlerinden en yüksek, duruma ilişkin duygulardan $(6,58 \pm 1,67)$ en az puan alındı. Hastaların çoğu $(\% 79,1)$ eğitim istemekte ve eğitim konusunu \%41,5'i hastalık hakkında olarak ifade etti. Hastaları öğrenme ihtiyaçları puanları ile eğitim isteme durumu arasında anlamlı ilişki saptandı ( $p>0.05)$. Nefroloji hastalarının çoğu eğitim istemektedir. Hastaların öğrenim gereksinimleri ölçeğine göre özellikle yaşam aktiviteleri ile tedavi ve komplikasyonlara ilișkin bilgi almak istedikleri sonucuna varıldı. Eğitimlerin bu öncelik sırası doğrultusunda bireysel farklılıklar göz önünde bulundurularak planlanması önerilmektedir.
\end{abstract}

Anahtar Kelimeler: Nefroloji. Öğrenme İhtiyaçları. Hasta Eğitimi. Hemşirelik.

Determination of Learning Needs of Kidney Patients During Stay in Clinic

\begin{abstract}
This study was planned descriptive and cross-sectional conducted to determine the learning needs of kidney patients during stay in clinic. The study was conducted with 134 patients who accepted the study. Data were collected with prepared by the researches personal information form and "Patient Learning Needs Scale (PLNS)". Mann Whitney U test, Kruskal Wallis test and Spearman correlation analysis were performed for statistical analysis. Average age of the patients was $54.52 \pm 16.33$ years, duration of active disease was $5.5 \pm 6.4$ years and duration of hospital stay was $6.64 \pm 6.52$ days. $53 \%$ of the patients were female, $77.6 \%$ were married, the majority $(47.8 \%)$ were in primary school, and their economic status (91.0\%) was moderate. Age, gender, education, job, economic status were correlated with learning needs ( $>0.05)$. Average score of the Patient Learning Needs Scale of nephrology patients in the study was $83,12 \pm 19,30$. When the PLNS subscale scores were examined, life activities $(17,94 \pm 5,72)$ and treatment and complications $(17,04 \pm 5,50)$ were the highest and situation related emotions (6.58 \pm 1.67 ) were minimum score. Most of the patients (79.1\%) demanded education and $41.5 \%$ of the subjects stated that they are about the disease. A significant relationship was found between the learning needs scores of the patients and the demand for education ( $\mathrm{p}>$ 0.05). Most nephrology patients require education. According to Learning Needs Scale of patients, they wanted to get information especially about their life activities, treatment and complications. It is recommended the trainings should be planned in with this priority order taking to individual differences.
\end{abstract}

Key Words: Nephrology. Learning Needs. Patient Education. Nursing.

Geliş Tarihi: 10 Mayıs 2019

Kabul Tarihi: 19 Temmuz 2019

Dr. Aysel ÖZDEMiR

Bursa Uludağ Üniversitesi Sağlık Bilimleri Fakültesi

Halk Sağlığı Hemşireliği Anabilim Dalı

Bursa

Tel.: 02242942472

E-posta: ayozdemir@uludag.edu.tr
Böbrek hastalığı dünya genelinde 750 milyondan fazla kişiyi etkilemektedir ${ }^{1}$. Ülkemizde yapılan Türkiye Kronik Böbrek Hastalığı Prevalans Çalışma (CREDIT) kohortunda genel erişkin popülasyonda kronik böbrek hastalığı görülme prevalansı yüzde 15,7 bulunmuştur $^{2}$. Bu çalışmaya göre ülkemizde her 6-7 yetişkinden birinde çeşitli evrelerde böbrek hastalığı bulunmaktadır. Böbrek hastalıklarının sık görülmesi, mortalite ve morbiditenin yüksek olması, komplikas- 
yonların yaşam konforunu olumsuz etkilemesi hem aile hem de ülke ekonomisine yük getirmesi onu önemli bir halk sağlığı problemi haline getirmektedir² Günümüzdeki teknoloji ve bilimin kazandırdığı yenilikler sayesinde, sağlı hizmet maliyetlerinin ve hastane komplikasyonlarının artması hastaların hastanede yatış süresinin kısalmasına sebep olmuştur ${ }^{3}$. Hastaların hastanede kaldığı sürede hastalıkla ilgili bilgi, tutum ve becerilerinin belirlenmesi ve saptanan ihtiyaçların kazandırılması hastanın taburculuğu sonrası bakımında oldukça önemlidir ${ }^{4}$.

Hastaların belirlenen ihtiyaçlar doğrultusunda uygun ve yeterli bilgilendirme ile taburculuğa hazırlanmasında hemşirelere önemli roller düşmektedir ${ }^{3,4}$.

Aygül ve ark. (2012)'nın çalışmasında hastaların \%96,6'sı hasta yakınlarının bilgilendirilmesinin çok gerekli olduğunu tespit etmişlerdir ${ }^{5}$. Özdemir ve ark. (2015)'nın çalışmasında hastaların \%78,9'u eğitim gereksinimi olduğu saptanmıştır ${ }^{6}$. Eğitimin uygun ve yeterli düzeyde olabilmesi için hasta gereksinimlerinin tespit edilmesi, öncelik sırasına göre belirlenmesi, bireysel eğitimin kapsamlı olarak planlanması çok basamaklı bir girişimdir ${ }^{4}$. Taburculuk eğitimi verilen hastaların; iyileşme süreçlerinin hızlandığı, yan etkilerinin önlendiği tespit edilmiştir ${ }^{5}$. Bireylerin hastalıklarına ilişkin bakış açıları, onların yaşam kaliteleri üzerinde oldukça etkili olmaktadır. Özellikle kronik seyirli böbrek yetmezliği hastalarında, kendi hastalığına ilişkin görüşlerinin iyileştirilip, gereksinim duydukları bilgilendirmenin bütüncül yapılması yaşam kalitesinin yükseltilmesine yardımcı oluna bileceği düşünülmektedir ${ }^{7}$.

Hasta öğrenim gereksinimleri ile ilgili farklı kliniklerde birçok çalışma yapılmıştır. Fakat nefroloji kliniğinde yapılanlar sınırlıdır. Bu çalışmada böbrek hastalarının yatarak tedavi olduğu sürede öğrenim gereksinimlerinin saptanıp, eksikliği hissedilen bilgilerin tamamlanabilmesi için eğitimlerinin bu doğrultuda planlanmasına katkıda oluna bilineceği düşünülmektedir.

$\mathrm{Bu}$ çalışma, böbrek hastalarının klinikte yattığı süre içerisinde öğrenim gereksinimlerini belirlemek amacıyla gerçekleştirildi.

\section{Gereç ve Yöntem}

Çalışma, böbrek hastalarının klinikte yattığı süre içerisinde öğrenim gereksinimlerini belirlemek amacı ile kesitsel ve tanımlayıcı türde gerçekleştirildi. Araştırmanın evrenini 1 Mart-30 Nisan 2019 tarihleri arasında Bursa ilinde yer alan bir üniversite hastanesinin nefroloji kliniğine başvuran hastalar oluşturdu. Çalışmaya bu tarihler arasında Bursa Uludağ Üniversitesi Sağlık Uygulama ve Araştırma Merkezi Hastanesi’nin nefroloji kliniğinde yatan, iletişim sorunu olmayan, çalışmaya katılmayı kabul eden toplam 134 nefroloji hastası alındı. Çalışma verileri, nefroloji kliniğinde uygulamaya çıkan öğrencilerin bakım planı yaptıkları hasta bakım formlarından oluşturuldu.

\section{Veri Toplanması}

Araştırmanın verileri, Halk Sağlığı Hemşireliği klinik uygulama sırasında öğrencilerin yüz yüze görüşme tekniği ile nefroloji hastalarından elde ettikleri bilgilerle hazırlanan bakım planı formlarının, araştırmacılar tarafindan taranması ile elde edildi. Veriler 24 sorudan oluşan kişisel bilgi formu ile Bubela ve arkadaşları (1990) tarafindan geliştirilen, Türkçe geçerliği ve güvenirliği Çatal ve Dicle (2007) tarafından yapılan Hasta Öğrenim Gereksinimleri Ölçeği (HÖGÖ) ile toplandı. Literatürde yer alan bilimsel çalışmaların çoğunluğunda hasta öğrenim gereksinimini belirlemek için HÖGÖ kullanılmıştır.

Kişisel Bilgi Formu: Hastalara ait sosyo-demografik özellikler (yaş, cinsiyet, öğrenim durumu, meslek, medeni hal, gelir durumu vb.) ile hastalığa ilişkin özellikler (ailede kronik hastalık varlığı, hastanede kalış süresi, refakatçi durumu, aktif hastalık süresi, hastane deneyimi vb.) ve hasta eğitimine yönelik (daha önce hastalıkla ilgili eğitim durumu, eğitim isteği, eğitim istenilen konu, yöntem ve zaman vb.) bilgileri içeren toplamda 24 sorudan oluşmaktadır.

Hasta Öğrenim Gereksinimleri Ölçeği: Hasta Öğrenim Gereksinimleri Ölçeği Bubela ve arkadaşları (1990) tarafından geliştirilmiş, Türkçe geçerlik ve güvenirliği Çatal ve Dicle (2007) tarafından yapılmıştır. Ölçek likert tipi toplam 50 madde ve 7 alt gruptan (ilaçlar, yaşam aktiviteleri, toplum ve izlem, duruma ilişkin duygular, tedavi ve komplikasyonlar, yaşam kalitesi, cilt bakımı) oluşmaktadır. Her madde 1'den 5'e kadar puan alır. (1= önemli değil, $2=$ biraz önemli, $3=$ ne az ne çok önemli, $4=$ çok önemli, $5=$ son derece önemli) Ölçekten ortalama bir puan elde edilebilir ve toplam puan 50-250 arasında değişmektedir. Ölçek her bir alt grup ile ölçek toplam puanı üzerinden değerlendirilmektedir. Ölçekten elde edilen toplam puanın artması kişilerin öğrenim gereksinimlerinin arttığını göstermektedir. Ölçeğin Cronbach alpha değeri 0,95 olarak belirlenmiştir ${ }^{8}$.

\section{İstatistiksel Analiz}

Araştırmadan elde edilen veriler bilgisayar ortamında SPSS (Statistical Package for Social Sciences) for Windows 20.0 programında ortalama, yüzdelik, Mann Whitney U test, Kruskall Wallis testi ve Spearman korelasyonu kullanılarak analiz yapıldı. İstatistik anlamlılık düzeyi $\mathrm{p}<0,05$ olarak kabul edildi.

\section{Etik Boyutu}

Araştırmanın yapılabilmesi için Bursa Uludağ Üniversitesi Sağlık Bilimleri Araştırma ve Yayın Etik Kurulu'ndan etik onay alınd1. (Oturum Tarihi: 12.02.2019 ve 2019-03 Oturum Sayıs1, Karar No 11) 


\section{Bulgular}

Böbrek hastalarının sosyo-demografik özellikleri ile hasta ve hastalığa ilişkin bilgileri Tablo I'de gösterilmiştir.

Hastaların yaş ortalaması $54,52 \pm 16,33$ yıldır. Hastaların \%53'ü kadın ve \%77,6'sı evlidir. Bireylerin çoğunluğu $(\% 47,8)$ ilkokul mezunu ve ekonomik durumları $(\% 91,0)$ orta düzeydedir. Araştırmaya katılan bireylerin neredeyse tamamı $(\% 96,3)$ daha önce hastanede yattığ 1 ve $\% 97,8$ 'inin yanında refakatçısı olduğu görülmektedir. (Tablo I)

Tablo I. Nefroloji hastalarının sosyo-demografik özelliklerinin dağılımı

\begin{tabular}{|c|c|c|c|}
\hline Özellikler & $\begin{array}{c}\text { Ortalama } \\
\text { 土Standart Sapma }\end{array}$ & $\mathrm{n}$ & $\%$ \\
\hline Yaş & $54,52 \pm 16,33$ & & \\
\hline Aktif hastalık süresi(yıl) & $5,5 \pm 6,4$ & & \\
\hline Hastanede yatış süresi(gün) & $6,64 \pm 6,52$ & & \\
\hline \multicolumn{4}{|l|}{ Cinsiyet } \\
\hline Kadın & & 71 & 53 \\
\hline Erkek & & 63 & 47 \\
\hline \multicolumn{4}{|l|}{ Medeni durum } \\
\hline Evli & & 104 & 77,6 \\
\hline Bekâr & & 7 & 5,2 \\
\hline Dul & & 23 & 17,2 \\
\hline \multicolumn{4}{|l|}{ Öğrenim durumu } \\
\hline Okuryazar değil & & 4 & 3 \\
\hline Okuryazar & & 4 & 3 \\
\hline illkokul & & 64 & 47,8 \\
\hline Ortaöğretim & & 30 & 22,4 \\
\hline Üniversite & & 25 & 18,7 \\
\hline Diğer & & 7 & 5,2 \\
\hline \multicolumn{4}{|l|}{ Meslek } \\
\hline Serbest meslek & & 6 & 4,5 \\
\hline 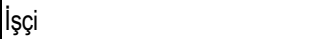 & & 7 & 5,2 \\
\hline Memur & & 17 & 12,7 \\
\hline Emekli & & 31 & 23,1 \\
\hline Ev Hanımı & & 58 & 43,3 \\
\hline Diğer & & 15 & 11,2 \\
\hline \multicolumn{4}{|l|}{ Ekonomik durum } \\
\hline liyi & & 9 & 6,7 \\
\hline Orta & & 122 & 91,0 \\
\hline Kötü & & 3 & 2,2 \\
\hline \multicolumn{4}{|l|}{ Refakatçı durumu } \\
\hline Var & & 131 & 97,8 \\
\hline Yok & & 3 & 2,2 \\
\hline \multicolumn{4}{|l|}{ Hastane yatış deneyimi } \\
\hline Evet & & 129 & 96,3 \\
\hline Hayır & & 5 & 3,7 \\
\hline
\end{tabular}

Nefroloji hastalarının \%79,1'inin eğitim istediği, \%41,5'inin hastalıkları hakkında eğitim istediği saptandı. Hastaların \%83,1'nin bu eğitimi hastanede yatarken ve \%98,1'inin bu eğitimi yüz yüze yöntem kullanılarak verilmesini istediği tespit edildi. (Tablo II)
Tablo II. Nefroloji hastalarının hasta eğitiminden isteklerinin dağılımı

\begin{tabular}{|lcc|}
\hline Hastaların Hasta Eğitim İstekleri & $\mathbf{n}$ & $\%$ \\
\hline Eğitim isteği (n=134) & & \\
Evet & 106 & 79,1 \\
Hayır & 28 & 20,9 \\
\hline Eğitimin zamanı (n=106) & \\
Taburculuktan hemen önce & 17 & 16 \\
Yatış sırasında & 88 & 83,1 \\
Her müdahaleden önce & 1 & 0.9 \\
\hline Eğitim için tercih edilen yöntem (n = 106) & & \\
Yüz yüze & 104 & 98,1 \\
Sadece kitapçık / broşür kullanarak & 2 & 1,9 \\
\hline Eğitim istenilen konular (n = 106) & & \\
Diyetleri hakkında & 16 & 15 \\
lilaçlar / tedavi hakkında & 18 & 17 \\
Hastalık hakkında & 44 & 41,5 \\
Günlük yaşama etkisi hakkında & 16 & 15 \\
Koruyucu önlemler hakkında & 12 & 11,5 \\
\hline
\end{tabular}

Nefroloji hastalarının Hasta Öğrenim Gereksinimleri Ölçeği'nden (HÖGÖ) ve alt gruplarından elde edilen puanların dağılımı Tablo III’te görülmektedir. Hastalarının Hasta Öğrenim Gereksinimleri Ölçeği toplam puanı 83,12 $\pm 19,30$ 'dur. Hastaların ölçeğin yaşam aktiviteleri ile tedavi ve komplikasyon alt bölümlerinden en yüksek puan aldığı belirlendi.

Tablo III. Hasta öğrenim gereksinimleri ölçeğinden ve alt gruplarından elde edilen puanların dağılımı

\begin{tabular}{|lccc|}
\hline HÖGÖ Alt Grupları & Ort $\pm S d$ & Minimum & Maximum \\
\hline İlaçlar & $12,13 \pm 5,45$ & 8,00 & 32,00 \\
\hline Yaşam aktiviteleri & $17,94 \pm 5,72$ & 9,00 & 32,00 \\
\hline Toplum ve izlem & $7,93 \pm 1,93$ & 6,00 & 15,00 \\
\hline Duruma ilişkin duygular & $6,58 \pm 1,67$ & 5,00 & 14,00 \\
\hline Tedavi ve komplikasyonlar & $17,04 \pm 5,50$ & 9,00 & 31,00 \\
\hline Yaşam kalitesi & $14,26 \pm 4,44$ & 8,00 & 26,00 \\
\hline Cilt bakımı & $7,21 \pm 2,78$ & 5,00 & 16,00 \\
\hline HÖGÖ toplam puanı & $\mathbf{8 3 , 1 2 \pm 1 9 , 3 0}$ & $\mathbf{5 0 , 0 0}$ & $\mathbf{1 3 2 , 0 0}$ \\
\hline
\end{tabular}

Tablo IV incelendiğinde yaş, cinsiyet, eğitim, meslek, ekonomik durum gibi sosyo-demografik değişkenler hastaların öğrenme ihtiyaçları ile korelasyon gösterdi $(\mathrm{p}>0.05)$. Ailede kronik hastalığa sahip olma durumu ve hastanede yatma durumu ile öğrenme ihtiyaçları puanları istatistiksel olarak anlamlılık göstermedi. Hastalık süresi ile tedavi ve komplikasyonlar alt grubu arasında pozitif yönlü, hastanede yatış süresi ile ölçeğin yaşam aktiviteleri ve duruma ilişkin duygular alt grubu öğrenme ihtiyaçları arasında negatif yönlü anlamlı ilişki saptandı. ( $>0.05)$. Hastaların öğrenme ihtiyaçları puanları ile eğitim isteme durumu arasında ilişki tespit edildi( $p>0.05)$. 
Tablo IV. Bazı hasta değişkenlerinin HÖGÖ puanları üzerine etkisi

\begin{tabular}{|c|c|c|c|}
\hline 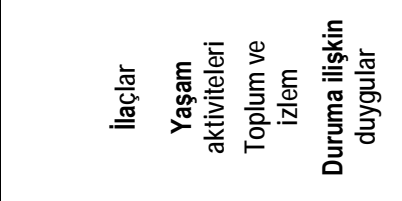 & 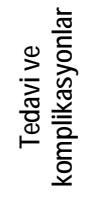 & 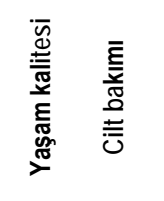 & 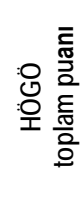 \\
\hline 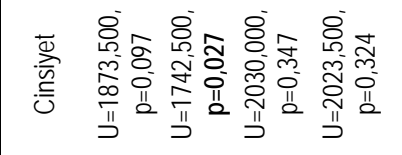 & 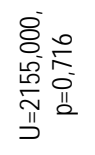 & 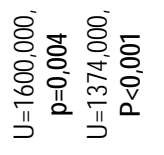 & 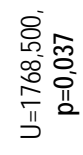 \\
\hline 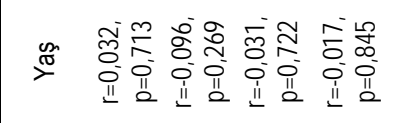 & 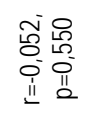 & 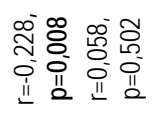 & 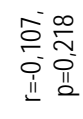 \\
\hline 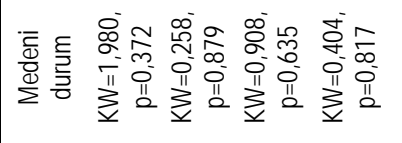 & 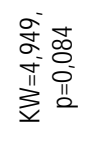 & 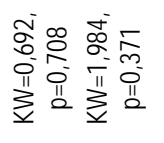 & 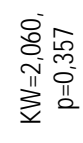 \\
\hline 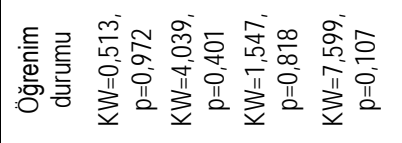 & 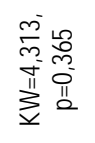 & 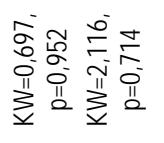 & 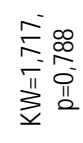 \\
\hline 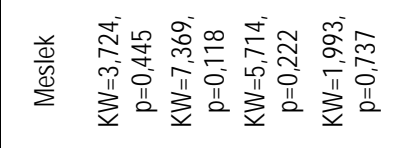 & 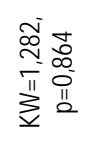 & 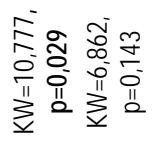 & 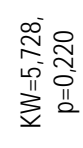 \\
\hline 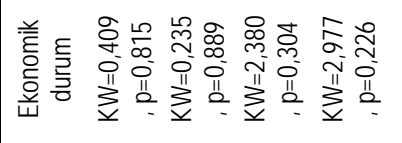 & 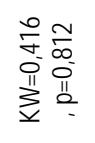 & 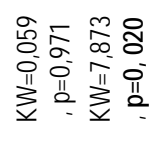 & 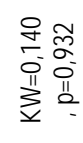 \\
\hline 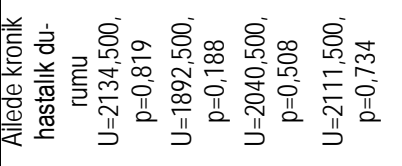 & $\begin{array}{l}8 \\
8 \\
0 \\
00 \\
0 \\
01 \\
\pi\end{array}$ & 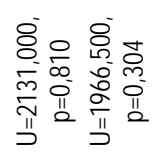 & 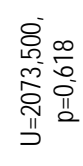 \\
\hline 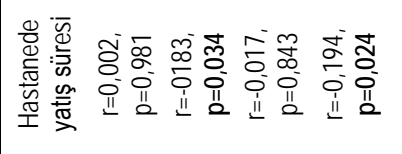 & $\begin{array}{l}00 \\
0 \\
0 \\
0 \\
0 \\
0 \\
11 \\
11\end{array}$ & 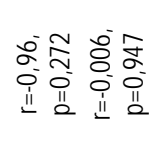 & 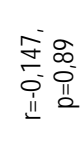 \\
\hline 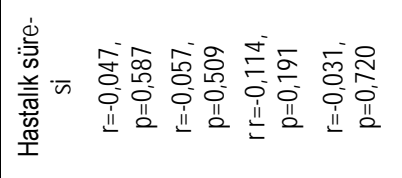 & 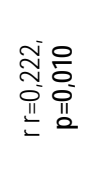 & 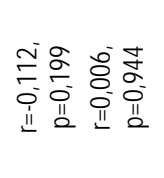 & 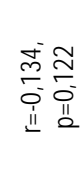 \\
\hline 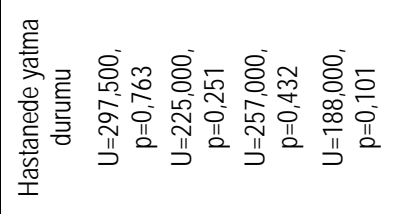 & 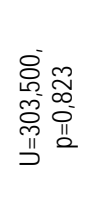 & 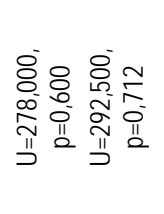 & 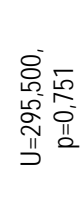 \\
\hline 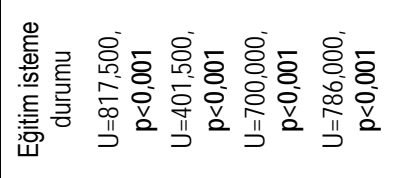 & 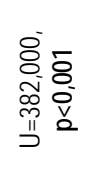 & 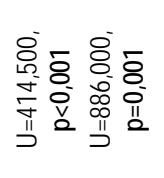 & 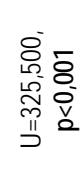 \\
\hline
\end{tabular}

U= Mann Whitney U testi, KW= Kruskall Wallis testi

\section{Tartışma ve Sonuç}

Bu çalışma, Bursa Uludağ Üniversitesi Sağlık Uygulama ve Araştırma Merkezi Hastanesi'nin nefroloji kliniğinde yatan, araştırmaya katılmayı kabul eden, Halk Sağlığı Hemşireliği uygulaması sırasında kullanılan tarama formları değerlendirilerek toplam 134 böbrek hastasının öğrenim gereksinimlerini belirlemek amacıyla tanımlayıcı ve kesitsel olarak gerçekleştirildi. Nefroloji hastalarına uygulanan Hasta Öğrenim Gereksinimleri Ölçeği (HÖGÖ) sonucunda elde edilen toplam puan çalışmamızda $83,12 \pm 19,30$ (minimim 50,00-maksimum 132,00) olarak tespit edildi. Aynı ölçek kullanılarak gerçekleştirilen bilimsel çalışma sonuçlarında ise HÖGÖ puanları Tan ve ark. bir üniversite hastanesine ait dahiliye kliniklerindeki (Nefroloji, Hematoloji, Endokrinoloji, Göğüs hastalıkları, Gastroloji, Onkoloji, Nöroloji) hastalarda 204,26 $\pm 23,85$, Çetinkaya ve Aşiret' in dahili ve cerrahi hastalarda $186.67 \pm 29.22$, Güçlü ve Kurşun'un genel cerrahi hastalarda $191.17 \pm 34.14$, Şahin ve ark. kolorektal kanser cerrahisi uygulanan hastalarda 199,6 \pm 29,7, Soyer ve ark. ameliyat olan (Organ Nakli Araştırma ve Uygulama Merkezi, Genel Cerrahi, Beyin ve Sinir Cerrahisi, Plastik, Rekonstrüktif ve Estetik Cerrahi, Ortopedi ve Travmatoloji, Üroloji, Göz Hastalıklar1) hastalarda $205.0 \pm 26.7$, Temiz ve ark. tiroidektomi yapılan hastalarda $208.38 \pm 34.91$, Polat ve ark. bir üniversite hastanesinde yatan hastalarda $165.95 \pm$ 45.44, Göktaş ve ark. cerrahi ünitesindeki hastalarda $178,53 \pm 27,59$ olarak hesaplanmıştır ${ }^{3,4,9-14}$. Çalışmanın gerçekleştirildiği örneklemde ele alınan hastalık çeşidinin farklılı̆̆ 1 ve çalışmamızın tek bir klinikte yapılmış olması HÖGÖ toplam puan ortalaması sonucunda değişiklik yaratmış olabilir.

Aynı ölçek kullanılarak farklı kliniklerde yapılan çalışmalara dahil edilen hastaların sosyo demografik verileri incelendiğinde Çetinkaya ve Aşiret'in büyük çoğunluğunun dahili kliniklerde $(\mathrm{n}=97)$ yatan hastalar tarafından oluşturulduğu hasta öğrenim gereksinimlerinin belirlenmesi adlı çalışmasında $(n=146)$ hastaların genel yaş ortalamasının $59.3 \pm 1,63$ yıl olduğu, büyük kısmının evli, ilköğretim ve altı eğitim düzeyine sahip, geliri giderinden az bireylerden oluştuğu tespit edilmiştir ${ }^{3}$. Yıldız ve ark. açık kalp cerrahisi geçirecek hastalarını $(n=114)$ çoğunluğu evli ve erkek, 61 ve üstünde yaşa sahip, ilkokul mezunu, herhangi bir işte çalışmayan, gelir durumu iyi olmayan bireyler oluşturmuştur $^{15}$. Dağ ve ark. jinekolojik ameliyat olan kadınların $(n=140)$ yaş ortalaması $47.29 \pm 1.46$, geneli ilköğretim mezunu, evli, herhangi bir işte çalışmamakta, ekonomik durumunu bildirenlerin çoğunluğu kötü olarak belirlenmiştir ${ }^{16}$. Bizim çalışmamızda ise nefroloji hastalarına $(\mathrm{n}=134)$ ait sosyo-demografik verilerin yer aldığı tablo 1 incelendiğinde yaş ortalaması

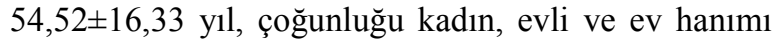


olan bireylerden oluşmaktadır. Ayrıca eğitim seviyesi ilkokul ve ekonomik düzeyinin orta olduğu kişiler yer almaktadır.

Göktaş ve ark. (n=291) cerrahi hastalar üzerinde yap1lan çalışmada hastaların \%52,6'sının $(n=153)$ daha önce hastane yatış deneyimi yaşadıkları, yaş ortalamaS1 $49.5 \pm 15,3$ y1l, çoğunluğu kadın, 61 ve üstü yaş grubunda, evli ve yüksek öğretim eğitim seviyesine sahip hastaların oluşturduğunu ifade etmişlerdir ${ }^{14}$. Dursun ve Y1lmaz'ın batın cerrahisi geçiren hasta grubunda \%71,5'inin daha önce hastane deneyimi olmadığı $1,47.36 \pm 16.16$ yaş ortalamasına sahip, çoğunluğu kadın, evli, ilkokul ve altı mezunu bireylerden oluşmuştur $^{17}$. Çalışma sonucumuzda ise bireylerin neredeyse tamamı $(\% 96,3)$ daha önce hastanede yatmıştır. Polat ve ark. bir üniversite hastanesinin dahili ve cerrahi kliniğinde yatan hastaların $(n=1190)$ çoğunun $(\% 58,7)$ hastanede yatış süresi 0-10 gün arası, Güçlü ve Kurşun'un cerrahi hastalarının $(n=114) \% 45,6$ 'sının 0-4 gün olarak tespit edilmiştir $^{9,13}$. Bizim çalışmamızda da hastaların hastanede yatış süresi ortalama $6,64 \pm 6,52$ gün olarak belirlenmiştir. Pehlivan ve ark. böbrek nakli olan hastaların hastalık süresi $10,58 \pm 6,26$, Özdemir ve ark. hematoloji hastalarının $(\mathrm{n}=57)$ ortalama $2.28 \pm 1.44$ yıldır $^{6,18}$. Bizim çalışmamıza dahil olan nefroloji hastalarının

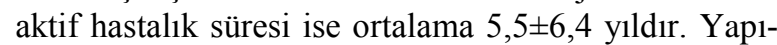
lan diğer bilimsel çalışma sonuçları ile nefroloji hastalarının sosyo-demografik durumlarının genelinde benzerlik olduğu görülmektedir.

Hasta eğitimi, hemşirelerin hasta ve ailesiyle iletişimde bulunmasını sağlayarak hasta-ailesinin gereksinimlerinin belirlenmesinde yadsınamayacak kadar kıymetlidir. Hemşirelerin temel sorumlulukları arasında hasta eğitimi önemli yer edinmektedir ${ }^{19}$. Çalışmamızda nefroloji hastalarının $\% 79,1$ 'i eğitim istediğini ve bu eğitimi yüz yüze, hastanede yatışı sırasında almak istediğini belirtmiştir. Çoğunluğun eğitim istediği çalışmamızda hastaların daha çok $(\% 41,5)$ hastalığa ilişkin konularda eğitim isteği olmuştur. Özdemir ve ark. hematoloji hastalarının $(n=57)$ öğrenim ihtiyaçlarını belirlemek amacıyla yaptıkları çalışmada da hastaların çoğunluğu eğitim istediklerini ifade etmişlerdir. Hastaların istediği bu eğitimleri hastanede yatışları sırasında, yüz yüze ve hastalık hakkında almak istedikleri tespit edilmiştir ${ }^{6}$. Çalışma sonuçlarına bakıldığında nefroloji hastalarının eğitim istekleri hematoloji hastalarınınkiyle paralellik göstermektedir. Vermişli ve ark. Kulak Burun Boğaz ve Baş Boyun cerrahisi (KBB ve $\mathrm{BBC}$ ) kliniğindeki hastaların \%87,8'i ameliyattan önce eğitim almak istediklerini, \%75,5’i bu eğitimi ameliyat sonrası ağrı kontrolü ve banyo ile ilgili konularda tercih etmişlerdir ${ }^{20}$. Bu farklılık cerrahi hastalarının operasyon ile ilgili yaşadığı stresten ve çalışmamıza göre daha genç yaş ortalamasına (44.4 \pm 15.2$)$ sahip bireylerden oluşan örneklem grubundan kaynaklanmış olabilir.
HÖGÖ alt boyut puanlarının dağılımı (Ort \pm SS) incelendiğinde çalışma sonucumuzda yaşam aktiviteleri $(17,94 \pm 5,72)$ ile tedavi ve komplikasyonlar $(17,04 \pm 5,50)$ bölümlerinden en fazla puan alınmıştır. HÖGÖ’nün kullanıldığı bilimsel araştırmalar incelendiğinde çalışma bulgularımızla eş sonuçların elde edildiği görülmektedir ${ }^{4,10,17,20,21}$. Bulgular doğrultusunda hastalığa ait tedavi süreci ve yaşam aktiviteleri ile ilgili hastaların daha çok bilgi ihtiyacının bu alanlarda olduğunu düşünebiliriz. Yılmaz ve Özkan'ın cerrahi hastalarında ilaçlar ve yaşam kalitesi, Pehlivan ve ark. böbrek nakli hastalarında yaşam kalitesi ve duruma ilişkin duygular en yüksek puan ortalamalar1na sahiptir ${ }^{18,22}$. Bu farklılık örneklem grubumuzdaki hastaların aktif hastalı süresinin $(5,5 \pm 6,4$ yıl $)$ Pehlivan ve ark. çalışmasına (10.58 $\pm 6,26$ yıl) göre nispeten daha kısa olup, sürenin yaşam konforu ve duygular üzerine etkisi daha zayıf kalabileceğinden öğrenim gereksinimini farklı yönde etkilemiş olabilir. Çalışmamızda HÖGÖ alt gruplarından en düşük puan ise duruma ilişkin duygulardan $(6,58 \pm 1,67)$ elde edilmiştir. Literatürde çalışma sonucumuzu destekleyen çalişmalar mevcuttur $3,8,10,12,16,23$.

Çalışmamızda hastalardaki bazı parametrelerin HÖGÖ alt boyut puanları üzerindeki gücüne bakıldığında sosyo-demografik özelliklerden cinsiyet ile yaşam aktiviteleri $(p=0,027)$, yaşam kalitesi $(p=0,004)$ ve cilt bakımı $(\mathrm{p}<0,001)$ alt grupları; yaş ve meslek ile sadece yaşam kalitesi alt grubu (sırasıyla $p=0,008$, $\mathrm{p}=0,029)$, ekonomik durum ile cilt bakımı $(\mathrm{p}=0,020)$ alt grubu arasında anlamlı fark saptanmıştır. Ailede kronik hastalığa sahip olma durumu ve hastanede yatma durumu ile ögrenme gereksinim puanları istatistiksel olarak anlamlılık göstermedi. Fakat hastalık süresi ile tedavi ve komplikasyonlar alt grubu arasında pozitif yönlü, hastanede yatış süresi ile ölçeğin yaşam aktiviteleri ve duruma ilişkin duygular alt grubu öğrenme ihtiyaçları arasında negatif yönlü anlamlı ilişki saptand1.(sırasiyla $\mathrm{p}=0,010, \mathrm{p}=0,034, \mathrm{p}=0,024)$ Göktaş ve ark. cerrahi hastaları ile çalışmasında cinsiyet ile ilaçlar ve duruma ilişkin duygular alt grubu, yaş ile HÖGÖ tüm alt grupları (ilaçlar, yaşam aktiviteleri, toplum ve izlem, duruma ilişkin duygular, tedavi ve komplikasyonlar, yaşam kalitesi, cilt bakımı) arasında, eğitim düzeyi ile ilaçlar, yaşam aktiviteleri, tedavi ve komplikasyonlar, yaşam kalitesi ölçek alt boyutları arasında anlamlı farklılık görülmüştür ${ }^{14}$. Tan ve ark. bir üniversite hastanesinin dahiliye kliniğinde yatan hastaların yatış süresi ile yaşam aktiviteleri, tedavi ve komplikasyon alt grupları arasında, cinsiyet ile cilt bakımı arasında, yaş ile ilaçlar, toplum ve izlem, duruma ilişkin duygular, tedavi ve komplikasyon HÖGÖ alt grupları arasında istatistiksel olarak anlamlı fark saptanmıştır ${ }^{4}$. Demirkıran ve Uzun'un ilk defa koroner arter bypass greft (KABG) ameliyatı geçiren hastaların öğrenim gereksinimlerinde cinsiyet ve mesleğin etkili olduğu, yaş, medeni durum, aile yapısı ve oturulan yer gibi diğer sosyo demografik değişkenlerin 


\section{Eskicioğlu, ark.}

etkili olmadığı bulunmuştur ${ }^{21}$. Bu doğrultuda hastaların cins, yaşlarına göre hasta öğrenim ihtiyaçlarının da farklılaşabileceği göz önünde bulundurulmalıdır.

Sonuç olarak böbrek hastalıkları kişilerin yaşam konforunu etkileyebilen, morbidite ve mortalitesi oldukça yüksek ve yaygın görülen önemli halk sağlığı sorunlarındandır. Ülkemizde ve dünyada giderek artış göstermesi, bireylerin böbrek hastalıkları hakkındaki farkındalığını arttırarak, bilgi eksikliğini de beraberinde getirmektedir. Çalışmamızda hastaların çoğunluğunun bilgi gereksiniminin fazla olduğu saptanmıştır. Hastaların en fazla bilgiye gereksinim duyduğu kısım yaşam aktiviteleri ile tedavi ve komplikasyonlar alt boyutundadır. Yaş, cinsiyet, eğitim, meslek, ekonomik durum ile öğrenme ihtiyaçlarının korelasyon gösterdiği belirlendi $(p>0.05)$. Eğitimlerin bu öncelik sırası doğrultusunda bireysel farklılıklar (yaş, eğitim, meslek, ekonomik, durum vb.) göz önünde bulundurularak bütüncül bakış açısıyla taburculuk eğitimi planlanması ve hastanelerde bu eğitim programlarından sorumlu eğitim hemşiresinin bulunması önerilmektedir.

\section{Kaynaklar}

1. Crews DC, Bello AK, Saadi G, World Kidney Day Steering Committee. Burden, Access, and Disparities in Kidney Disease. Nephron 2019;141(4):219-226.

2. T.C. Sağlık Bakanlığı Türkiye Halk Sağlığı Kurumu. Türkiye Böbrek Hastalıkları Önleme ve Kontrol Programı (2014-17) T.C. Sağlık Bakanlığı Yayın No=946. Ankara: Kızılay; 2014.

3. Çetinkaya F, Aşiret DG. Dahili ve Cerrahi Kliniklerindeki Hastaların Öğrenim Gereksinimlerinin Belirlenmesi. Dokuz Eylül Üniversitesi Hemşirelik Fakültesi Elektronik Dergisi 2017;10(2): 93-99.

4. Tan M, Özdelikara A, Polat H. Hasta Öğrenim Gereksinimlerinin Belirlenmesi. Florence Nightingale Hemşirelik Dergisi 2013;21(1):1-8.

5. Aygül S, Ulupınar S. Hemşirenin Hasta Eğitimindeki Rolüne Yönelik Hastaların Görüşleri. Anadolu Hemșirelik ve Sağlık Bilimleri Dergisi 2012;15(1):1-9.

6. Özdemir A, Yildız H, Akansel N. Learning Needs of Hematology Patients. International Journal of Caring Sciences 2015;8(3):577-584.

7. Yorulmaz H, Keçeci N, Tatar A. Kronik Böbrek Yetmezliğ Hastalarında Hastalık Algısının Yaşam Kalitesine Olan Etkisi. Literatür Sempozyum 2014; 1:40-45.
8. Çatal E. Hasta Öğrenim Gereksinimleri Ölçeği'nin Türkiye'de Geçerlik ve Güvenirlik Çalışması (Yüksek Lisans Tezi). İzmir: Dokuz Eylül Üniversitesi; 2007.

9. Güçlü A, Kurşun Ş. Genel Cerrahi Hastalarının Taburculuk Eğitim Gereksinimleri. Anadolu Hemşirelik ve Sağlık Bilimleri Dergisi 2017;20(2):107-113.

10. Şahin SY, İyigün E, Açıkel C. Kolorektal Kanser Cerrahisi Uygulanan Hastaların Bilgi Gereksinimlerinin Belirlenmesi. TAF Preventive Medicine Bulletin 2015;14(5):401-405.

11. Soyer Ö, Dönmez YC, van Giersbergen MY. Ameliyat Olan Hastaların Öğrenim Gereksinimlerinin Belirlenmesi. DEUHFED 2018;11(3):200-208.

12. Temiz Z, Ozturk D, Ugras GA, Oztekin SD, Sengul E. Determination of Patient Learning Needs after Thyroidectomy. Asian Pac J Cancer Prev 2016;17(3):1479-1483.

13. Polat S, Celik S, Erkan HA, Kasali K. Identification of learning needs of patients hospitalized at a University Hospital. Pakistan Journal of Medical Sciences 2014;30(6): 1253-58.

14. Göktaș SB, Yıldız T, Nargiz SK. The Evaluation of Nursing Care Satisfaction and Patient Learning Needs in Day Case Surgery. Indian J Surg 2015;77(3):1172-79.

15. Yıldız T, Malak A, Göktaş SB, Özen Y. Effect of Patient Education on Patient Anxiety Level Using "Scale of Patient Education Requirements" in Open Heart Surgery. Kosuyolu Heart Journal 2015;18(1):1-5.

16. Dağ H, Dönmez S, Güleç D ve ark. Jinekolojik Operasyon Geçiren Kadınların Taburculuk Öncesi Öğrenim Gereksinimleri. Ege Üniversitesi Hemşirelik Fakültesi Dergisi 2014;30(1):4959.

17. Dursun HB, Yılmaz E. Batın Cerrahisi Yapılan Hastaların Öğrenim Gereksinimleri. Celal Bayar Üniversitesi Sağlık Bilimleri Enstitüsü Dergisi 2015;2(3):65-70.

18. Pehlivan S, Vatansever N, Arslan İ, Yildiz A, Ersoy A. Level of Daily Life Activities and Learning Needs in Renal Transplant Patients. Experimental and clinical transplantation: official journal of the Middle East Society for Organ Transplantation 2019;1-7.

19. Kaya H. Sağlık Hizmetlerinde Hasta Eğitimi ve Hemşirenin Sorumlulukları. Turkiye Klinikleri J Nurs Sci 2009;1(1):19-23.

20. Vermişli S, Çukurova İ, Baydur H, Yılmaz E. Kulak Burun Boğaz ve Baş Boyun Cerrahisi kliniğinde cerrahi tedavi için yatan hastaların ameliyat öncesi hasta öğrenim gereksinimi ve kaygı arasındaki ilişki. Kulak Burun Bogaz Ihtis Derg 2016;26(2):79-91.

21. Demirkıran G, Uzun Ö. Koroner Arter Bypass Greft Ameliyatı Geçiren Hastaların Taburculuk Sonrası Öğrenim Gereksinimleri. Ege Üniversitesi Hemşirelik Fakültesi Dergisi 2012;28(1):112.

22. Yılmaz E, Özkan S. Cerrahi Hastaların Öğrenim Gereksinimleri. Anadolu Hemşirelik ve Sağlık Bilimleri Dergisi 2015;18(2):107-115.

23. Y1lmaz M. Learning needs of adult patients surgery. Cumhuriyet Medical Journal 2017;39(1):402-411. 